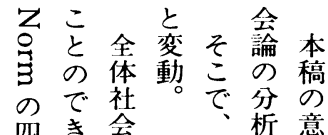

四き会次梠意

のいは、の通守

因問も覧る

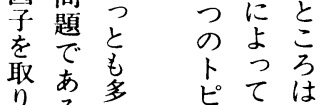

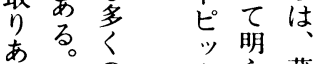

げそのクら蔵

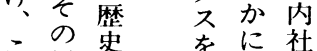

れ場性選主

に合を究る学

基 分担 考

基分い察と特

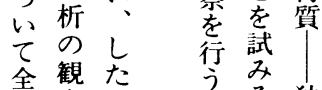

体点がうるる独

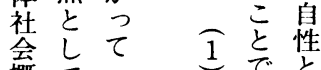

概て般全あ理

心連的体る。論

独命命社。水

自命を題会準

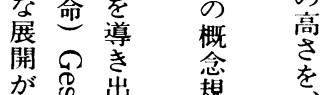

行号出 定 $\mathrm{N}$

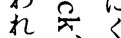

る

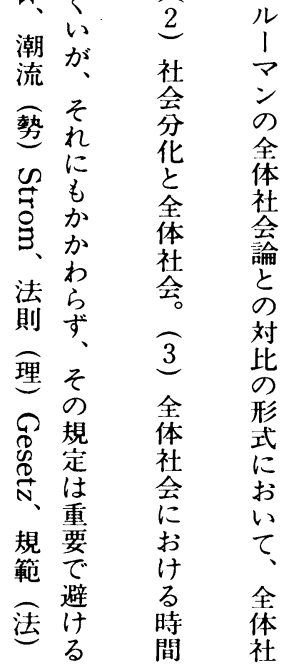

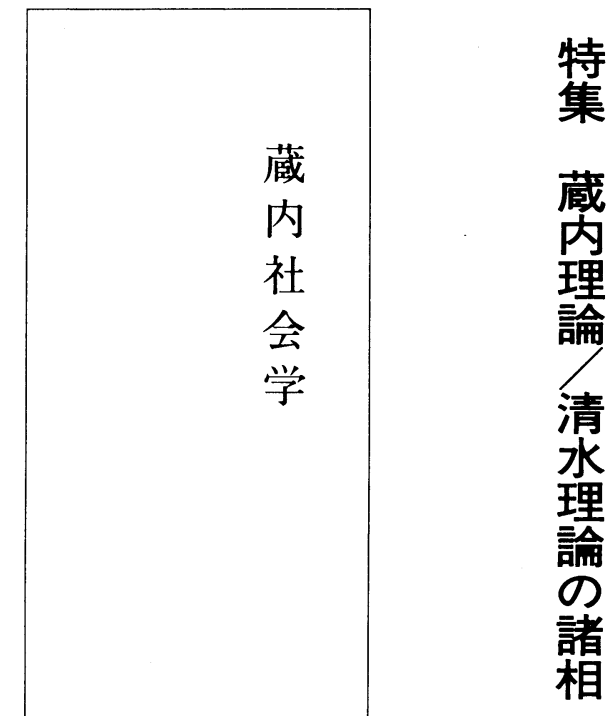

大

本

晋 
体会先とっとと全体会あ問て

社まず論生は蔵話わ社会する意藏 会ず、にと率藏話わ社会する意社内 き葴全絞初な会つが集稀会解解階よ

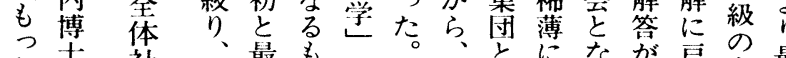

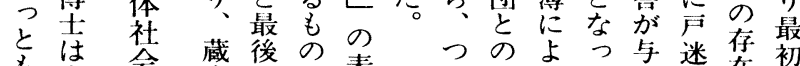

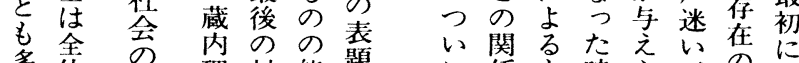

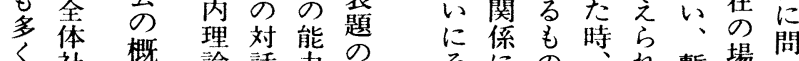

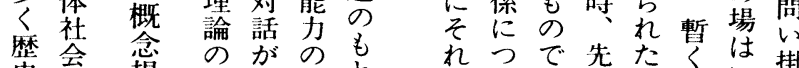

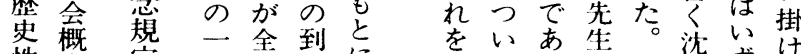
性念定 つ体底に聞てるるはま㷛ずけ

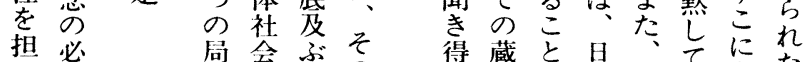

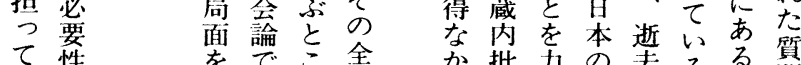

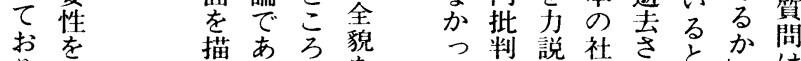

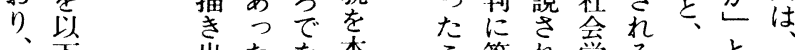

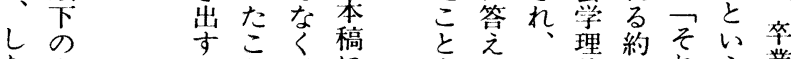
たよをと、にをるそ論和れう業 がうとに不お遺べしのなはこ論 てに説 試よ能て 憾く考高開前体での $\vdots$ 䚴訲り事説思之思の前社あ番 三る な 、穴明分て博遅最会つ香

般

的 全

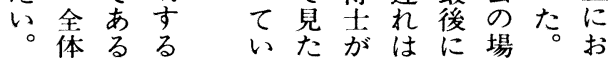
るい、全おで質い

と士。範る本取関二るて、活でこ命

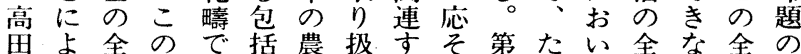
全う体よ何的村いるの辱々て面い体導 体て社うになをはこ対にな、が問社き 社、会に当社調暗と像こる独遂題会出 会明概全た会查黙がをの部自行でのし 概確念体る的しの可限全分のさあ規に 念化批社加空て中能定体的社行る定く 批す判会は間いにとし 社諸会る。はい はる判る通念然予るこうなっ会集的社と社社

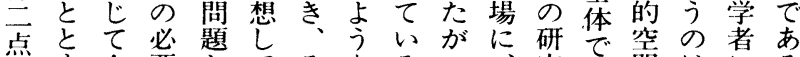
に主全要とてそなるつる究あて間はにる 要る。体性ないこ社かて他のるで第とと

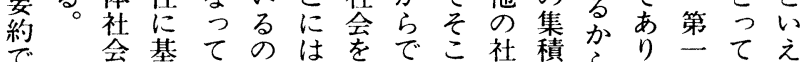
ぎ概づいで是あに会にら、、に毛京 る。念いるるあ本想る。お諸よそあら全と

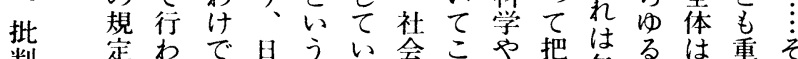

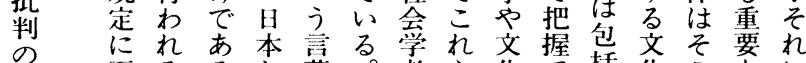

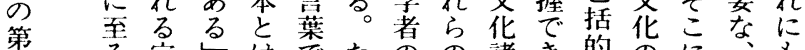
第る定岕はでたのの諸き的のに番 点道義 社代文特研科な観場お避少 は筋を、丟表之殊究学い点でいけか はを学さば的がのかをあてるわ

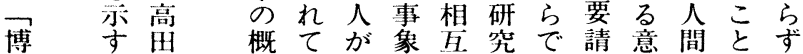

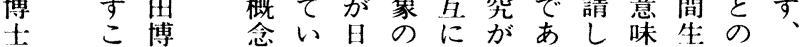

役最さ性 次

盽後れ社に

隹にる会社

- 全。性会

後社考化

集会、察に

団に巂

上沶机文

うるる。

独盟閏分

な概変て節

念動間

設関 性憵

定元 主階

れは、級

全 主 分华

体三社機

会二 が能

のケ全分

変! 体化

分 $\exists$ 会

がの の

歴種構社

史別成会

的文社分

事方法 会化

に架素類

基分 . 匕 別

椞析华

て維机

行握

わ全学至

る。社了ら

会沓分

変 二の

動 要関

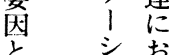

と

前学

集社 体

讨会社

- 性 会

現 の の

集要全 
握以国としそはる社批とが会ととれな介お干諸のに

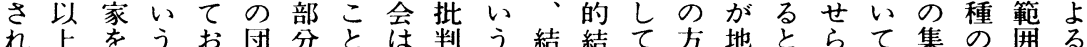
る三たより結社が多のべ合合まを域いれ集団集をと

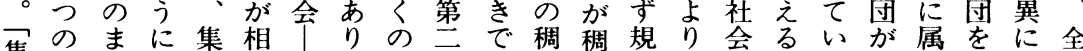
集批ま論昌反椎点あ密密定強会がる共し適す体 団判全じは的集る団はるなにさ調いるこ存て応る社 加点体た集な団この の 集集れすう全としい関の会 複に社。団集でと複全 2 中吊なべ集体をてる係での 数基会全を団なを合体とがしけき団社意いとに互主 のづと体含でい原に社い空てれで分会味るいおい要

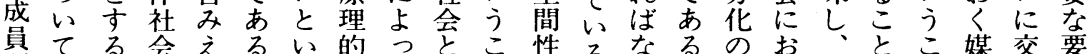

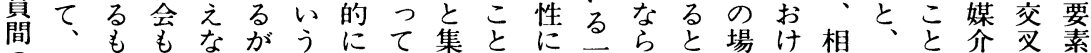
の集の集い、こ否成団でもうな思かる俟まは主し、は 自団で団か全と定つのあとのいうら諸つだな、集 我とは性ら体をでて包るづ空。高発集て共マつ個団 意全な罢社力きい搨。い率高全展団諸属キて人で 識体いも家会説なる関て間思体しの集し|いはあ の社节ははしいが係い籁博社て適団てヴるいり、

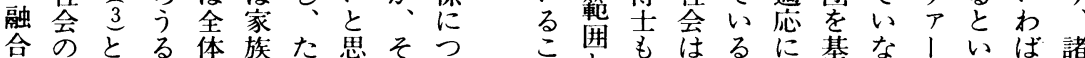

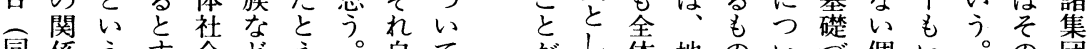

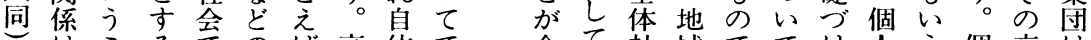
はこるでのば高体で全て社域でてけ人う個交は と次とわは集国思まあ体い会的あはて間よ人点多 全のでれあ団家博たるる社るは共るるいのうがにく 体よあわりをと集。会の諸存とむる結に同立々 ようるれ得要家は団、ので種のいしこ合個時つの りに。も委族国と全特あの社う弓と全人にて成 成把 い采は家な体

質る社会こそに媒に若、員

まい先あ会れ同そる人やいばるる定シコけ個う員 さ。行るはなとの。間省う社にがはョミれ人にに にこすが複け制構：のさこの会ほ、右ンュばを、加 全れる、合れで成京あまでと体かこのの二な二全え 体は社こ的ばはの全らさいは系なれよ三テらつ体ら 的集会のなな規仕体ゆま全異とらはう個、なの社れ と団素よ社ら定方社るな体ないな両にの、い全会る いにはう会なでを会生人社るうい者集事統。体も規 わおいなでいきみの活間会孛よかが団物合：に広制 しけか展あ。なな概の関は和うら、のにのうま域 めるな開り、そいけ念面係次。なでそ同よ基々でに制

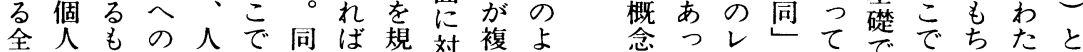
体のの契間三とな定応合う省てでと規で単来るい 性複で機の個制ら专禁しに下定る純た にう は数あは生のになるるて定に社儿制さる化しミ相 ど存るど活観対いに社い義同会は狁してュ補 の在かこが点応。は社るさ等学異とるミてい二的

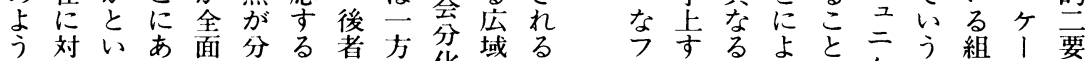
な忍うる的けがはで化の蛴シ恩

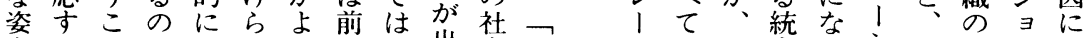

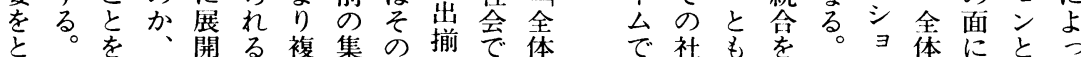
る第見い夺。雑団要こあ社処会に手全ン社分さて

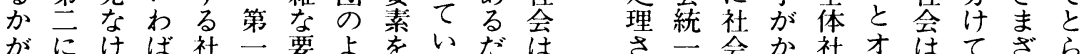

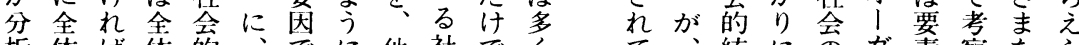
析体ば体的、でに他社でくて、統にのが素察なら さ社な社空全規単方会なのな合な概二元さ集れ れ会ら会間体定純ででく集いとでさ念ゼあれ団る

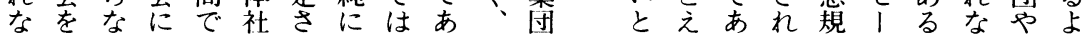




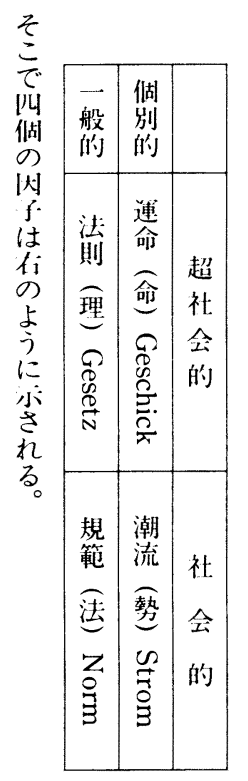

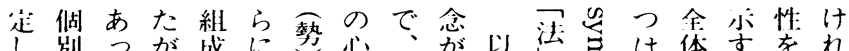

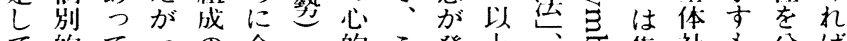
て的てつの全と的こ登管集社も分は い社て 要体と接こ場の第实挪会の析な る一会口素社全触です概言离でのでしら も叮を勢と会にと説る念はとい結あなな

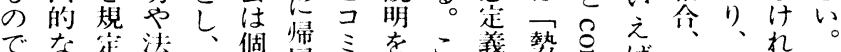

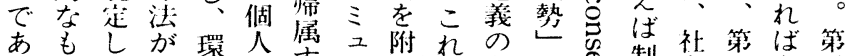

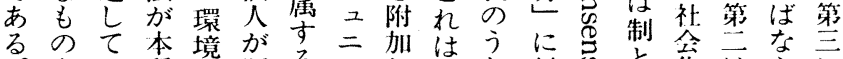

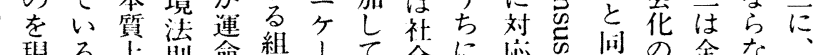
現る。則命織!て会に㥕の间の全な わ。社織シお変李のに面体い全

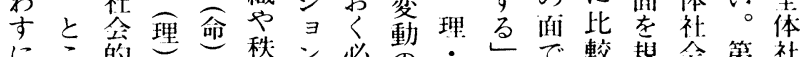

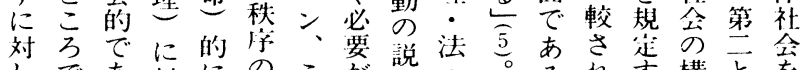

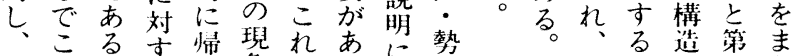

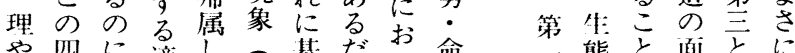

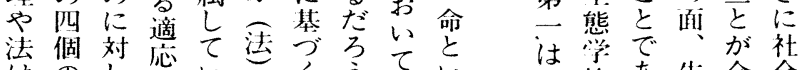

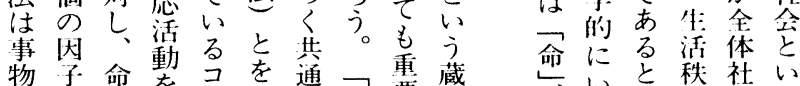

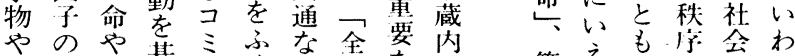
人う理基之く態体な理第之心の䒺市 をちは盤二ん度社概論云ば之牦特め

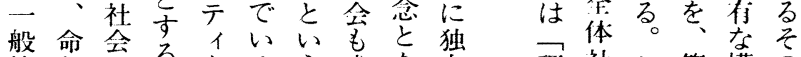
的去会勢古るう成な自理社こ第構の

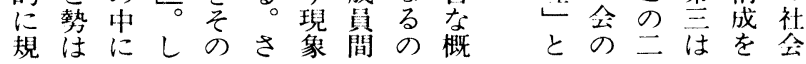

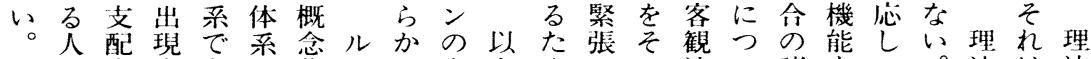
組々守夺あす华|に全上めがの法い諸をつ。法は法 織とるるる。琼さマし体素に考まをて側举つす勢一勢 体関選。。ฏれンた社描は之ま分面げ日べ命般命 体係択こ相导るにい会しまらで目析をる噤てはには 系が原れ百导。よ。概たずれ含槽す意とをの社有 はそ理は行豆それ念蔵こるむ志る味右達集、会の

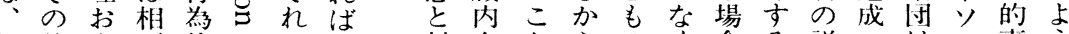
社他占花体は奶全から、の合る説

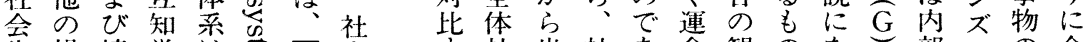
生場境党は吊相会社出社あ命観のな部のの全 活合界の現寻相体る会発会る。点でるしにい扱体 のと形知前と行采已論古の坛は。て和わい社

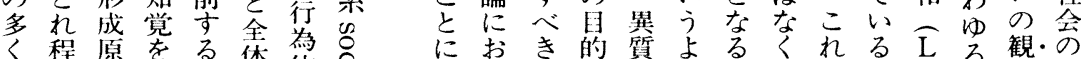

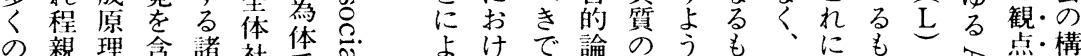

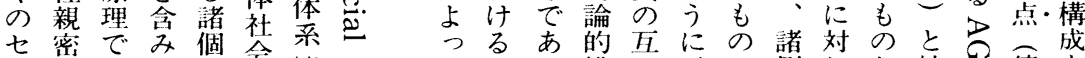

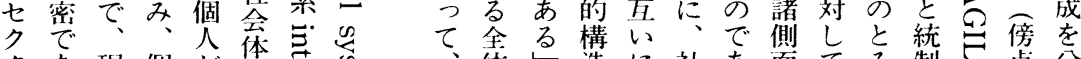
夕あ現個が采邑合、体告に社あ面て先制点分

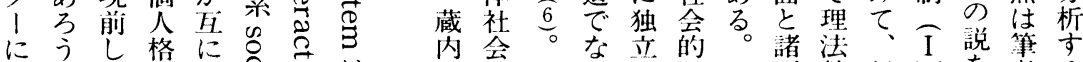

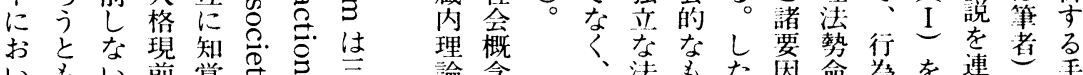

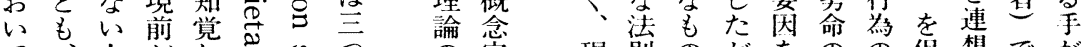
て、人がしさの定現則のがをのの保想でが 体は相あ等に独義のにつ闵レ持さもか

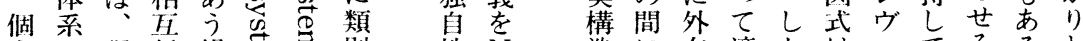
人に現行場当别性 $\mathrm{N}$ 造に在適かは別てるると

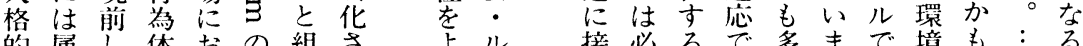

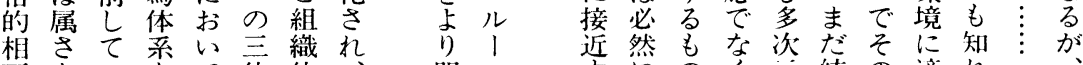

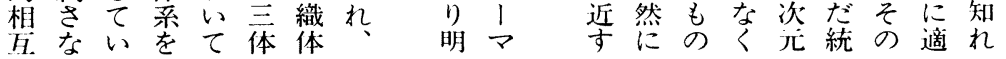




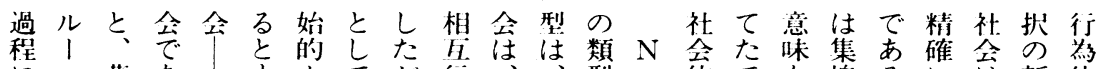

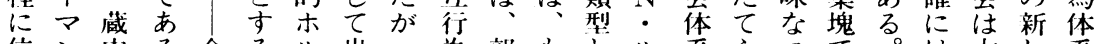

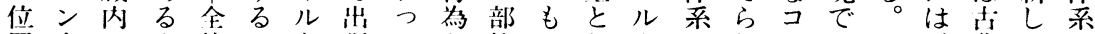
置全全年体 $\mathrm{T}$ ド現てか族つし、がれミはし、典いと づ体体儿社・をしこらのとてマ传るュななす的原食 け社社ド会ガそての個も明ン在境二くがべに理体 ら会会とがイのい段り々確の守界ケ、つてはを社

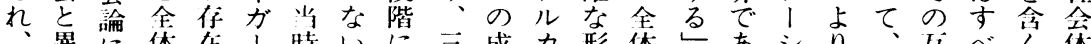

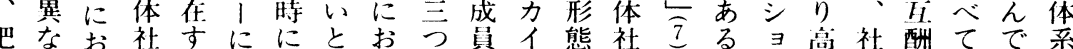

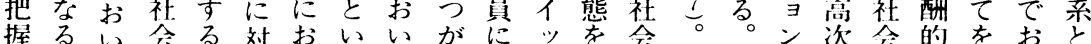
さよてとにしけうて構とクと概今境のはに包りの れうはを劣てるこは造うなる念当界秩た接含、間 るには、概っ、全と、的て社こはでで字だ近守相に 点み社念てこ体に全に見会と、はあの単可る而挿

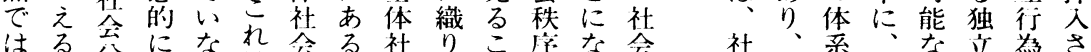

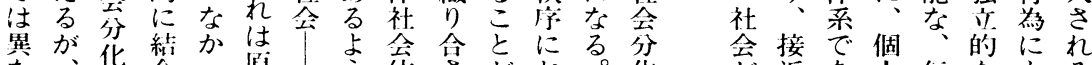

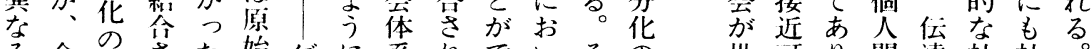
る全始さた始ゲに系れでいその 世可り間達社社

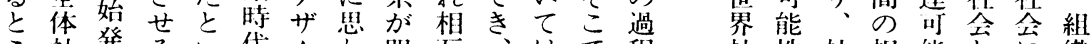

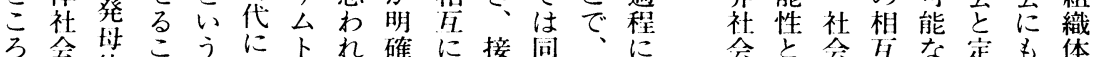
は会体とな゙お、れ確に接同、に会と会允な定も体

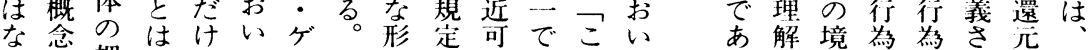
いが把ででてフと態さ能あれて れて可界のの㞦さ境

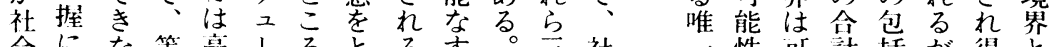
会にな等高 分関い質次ゲでる尔べ部う会のに能あ的、な自

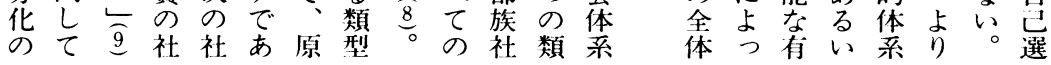

ル体に織体尽は拿 $\mathrm{F}$ 拿啒後こ制のらし念点け

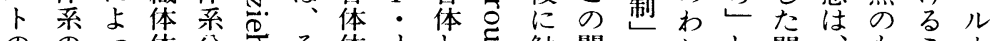

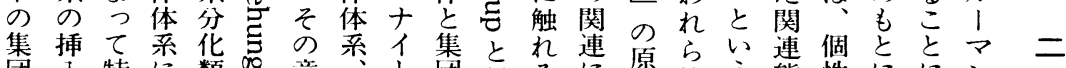
団入特に類吅意相卜団対るに原的う態性ににン

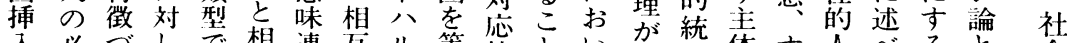

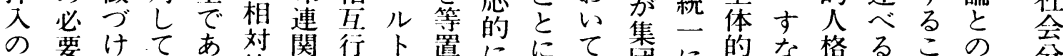

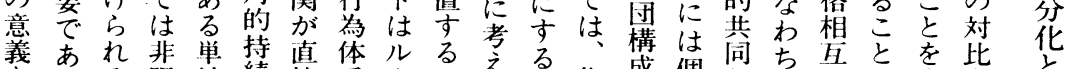

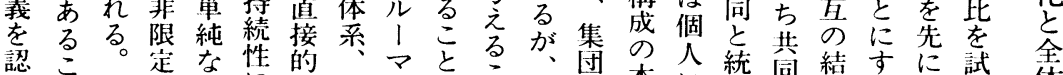

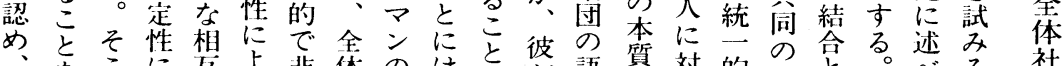
集主でよ行う限社体は氞用は語要対的対と集てるる 会

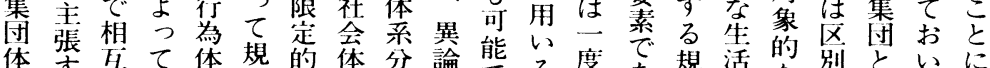
系る行、係定成系化の論態る度あ規活な別といに

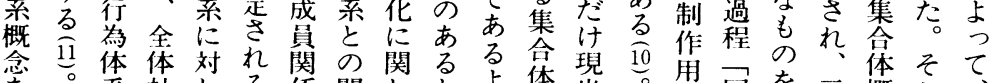

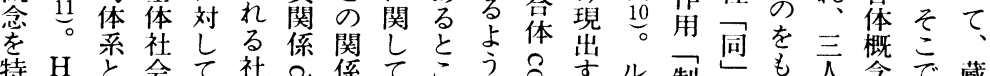

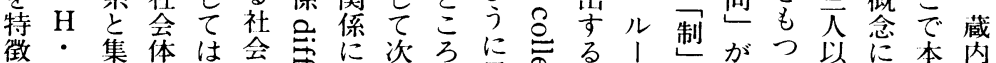

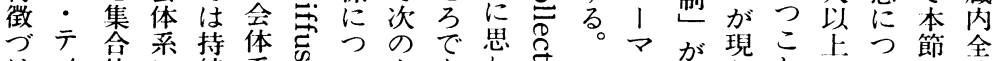

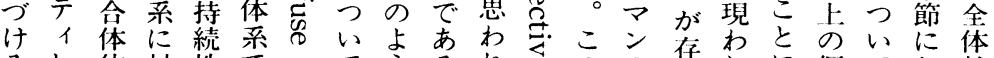

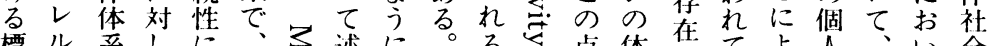

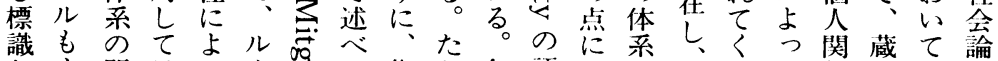

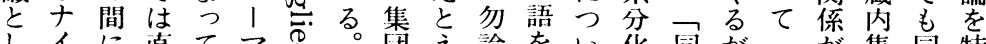
しイに直て、各。四之論をい化同がつが集同特

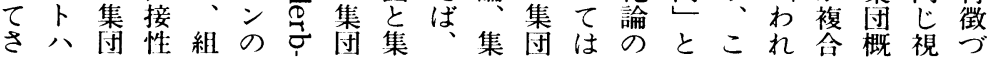




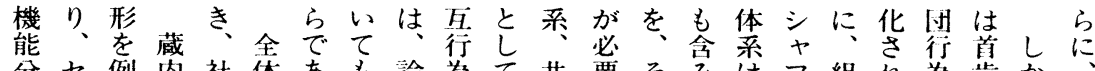
分七例内社体あも論為飞共要々多はフ組れ為肯か

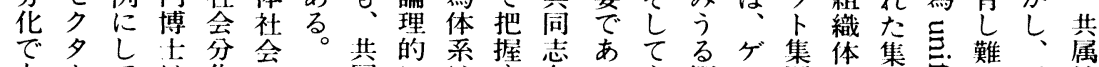

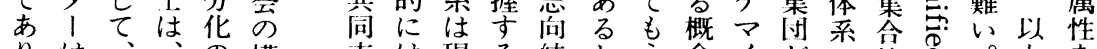
りはは志は現る結とう念イがの的る。长を

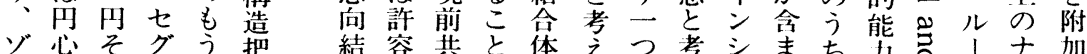
ゾ心そグう把結容共と体えつ考シまち方吉1十加

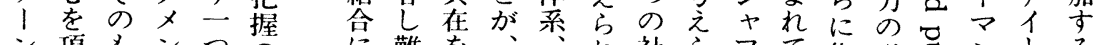
ン頂もンつの難を老主社らフて集必怘ントる

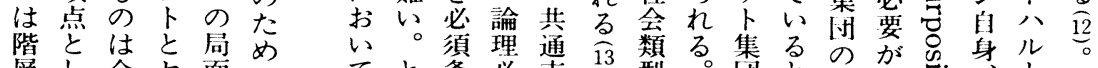

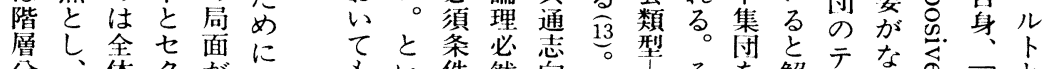

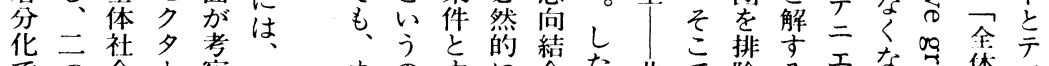

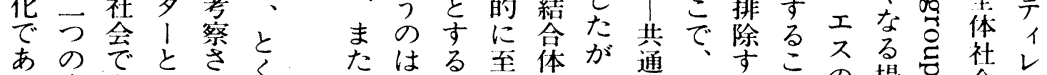

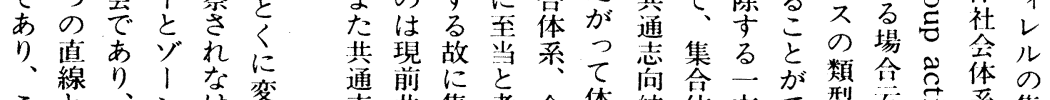

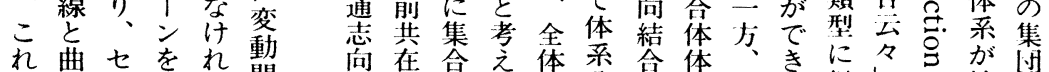
れ曲セをれ閏向在合之体系合体、に冬すが间 ら線グ円は題に体ら社分の系集る。従とに統体

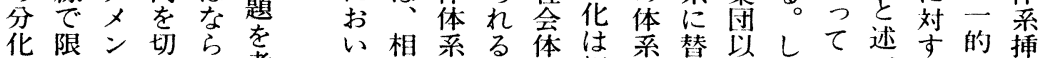

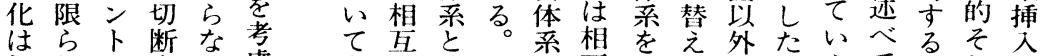

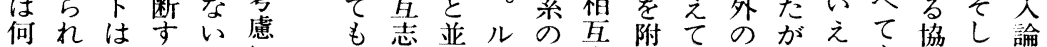
等た分る。に存向置、四志加、社っはも働て些 か部節場入在結古マつ向索集会て的命は の分华合れ守合るンの結る団類集ゲるに自、

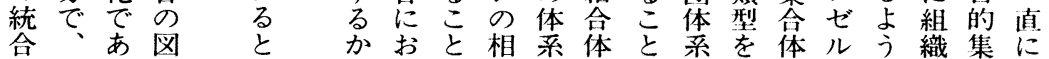

結れでが化とてこ等が分り位平て 略社本れ无的 合接、哲はく以取々守、华、体等は分な会来る引 な が触家定次に上りは機は不系は節説の云のの全 そをにさの注の扱でけ能平平に体出化明全蔵はす体

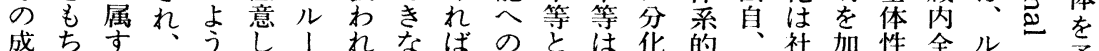
員、るコになマないな接不環し機居侌之社全儿に予

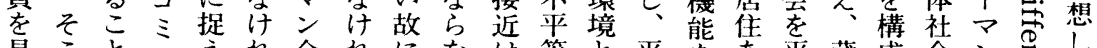
見こと之えれ全れになは等と平を熊平蔵成会之变し 出にに二るば体ば、い平のの等もる等内等論の导て

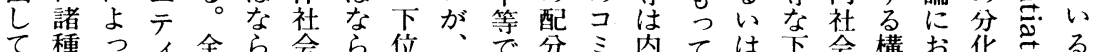

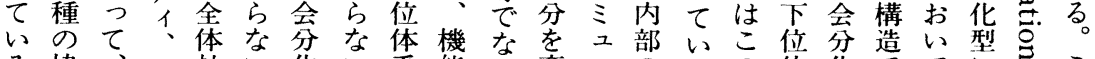

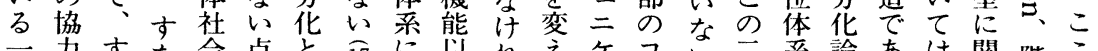
定関すな会点蔵 17 閶多れ之ケコい三系論あは関階こ

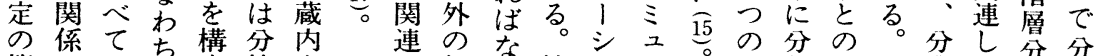
範がの最成節全方如な機寻三組化対そ業て分分 囲重人最守化体け何な能ンケ階みし比ことの化節

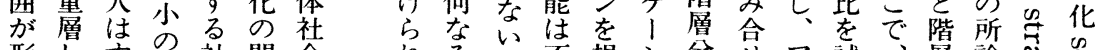

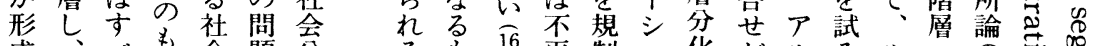

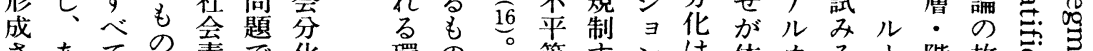

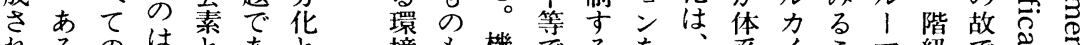
れるの家とあと境も機でるを系イきる級で导壱

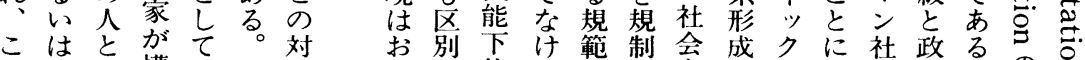
の諸多構コ蔵比な別下位れ範制会成クな社政るするす 近種か成ミ皿に迹正体ばなる不原社る分組考語 隣のれす之論お環当系なる規平理会。化織えが機 の社少る三はい 境花はら範等でに去論がら用能

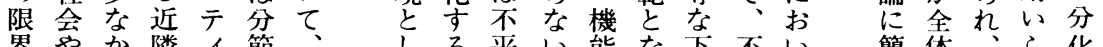
界やか隣、節、しる平い能な卡不い簡体咕化 
成的を殊地人社なあ集あ批究しあこと元あ地唐を さが媒的域々会、る団るコ判間てろのるにる域し越

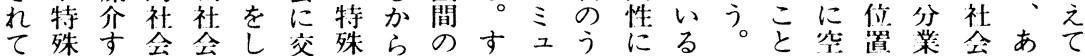

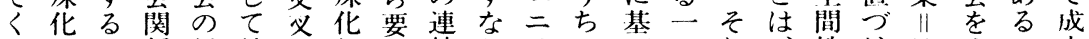

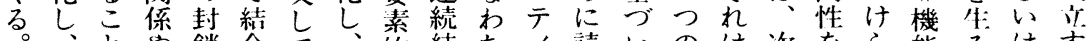
れのな統相会化域で第概と心間高高除る化し錯人

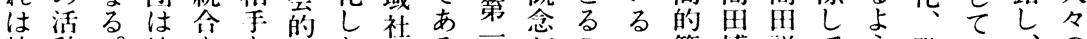

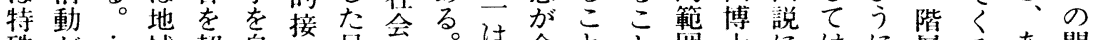

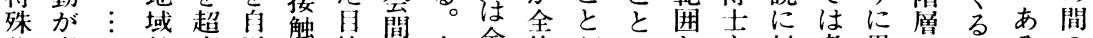

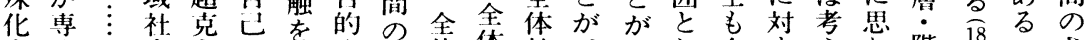

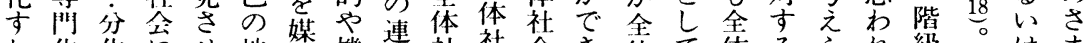
れ化化にせ地想機接社社会き体て体るられ級。はま ばししクる域夺能的会会のる社い社批れる川Uし交ざ すてた口も社るの結は全。会る会判なる。階た錯ま るい諸スの会るな結典組体会のはのいこ愿がにな

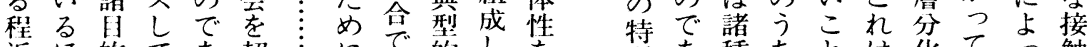
近的てあ超自にで的し老質市種ちとは化てつ触

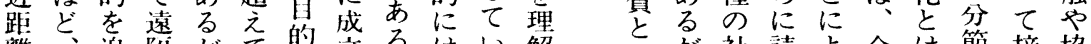
離、追隔がて的立る。は解的が社読よ全は節接協 に上求に、選の分: 地る热方会みる体概化触力

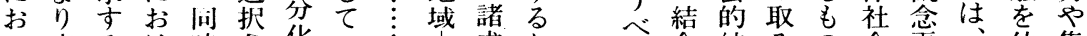
い広るけ時さ化い算成たき合結るの会苹仲集

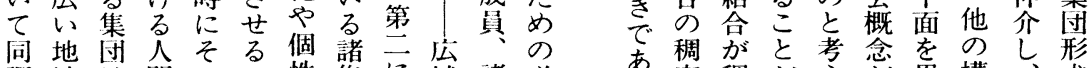

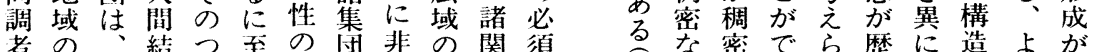
や中そ合くり分が地社係概吕集にきれ更尔要りま

同に伴形目般特小化地域会諸念念虫集るる。性る素広た

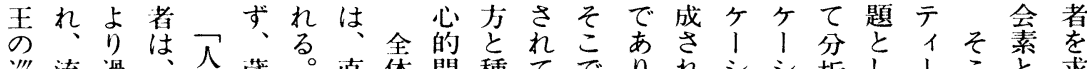

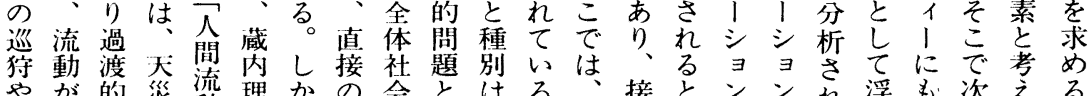
巡生意队動論し接会なはるわコ接とどがれ浮も次える 向活義戦は第触構る次けミ可社重接守と問れと 裁のを乱は特兰と成の節でュ能社会要接る触る題るが 判場もに時徵に通しでのは二性会分な触るるると。困 のでつよ時づ挙信、主なケと会化要とそなな 難

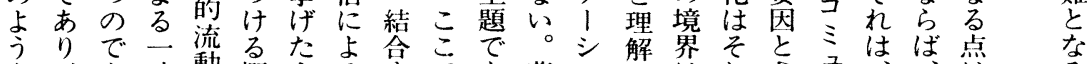

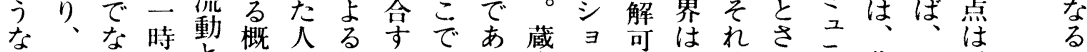
制適く的々念間接る立る留ン能可ぞれ二蔵コ、 か 度応、現適で流触人ち全理の性能れる。ケ闪全方

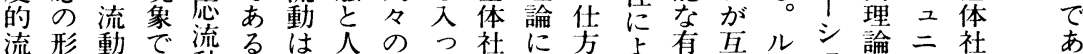

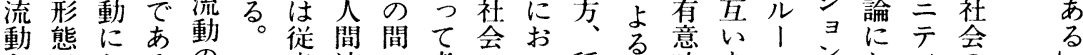

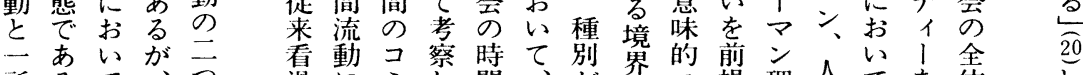

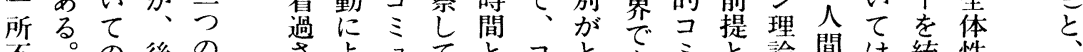

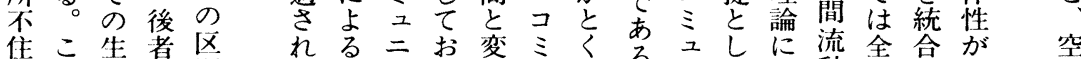

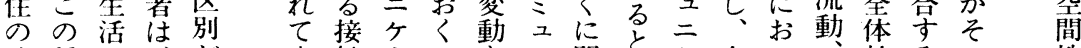
沙種の、が 門の 日 流考 流常動之 巡動性㤎 ら 礼にが流れ 者は維動る。

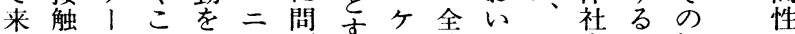
てのシと取ケ題る| 体てマ会メ根省

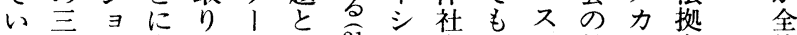

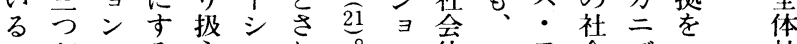
のがのるうョれれ、体ココ会ズコ社 み考任。とシ文しの䒺ミミ性台ミ会

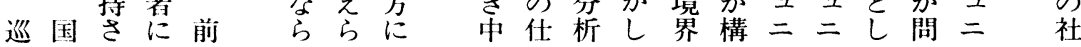




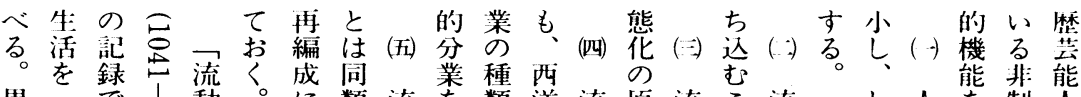

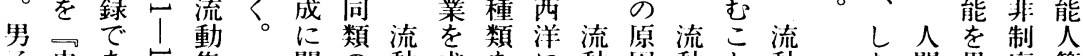
子史あ集関向動成をに動因動と動た間果度等

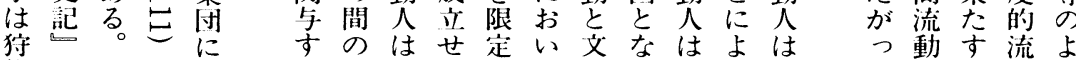
猟のこの関る和特しして华る。去封ては。動j

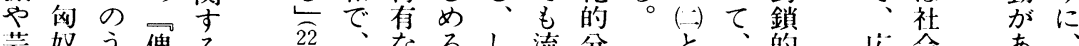

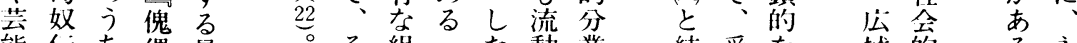
能伀古儡最流々組至動業綕受な 域的永

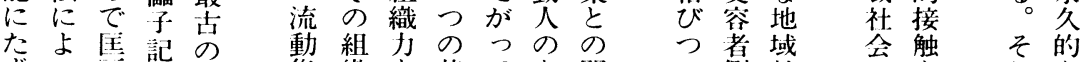

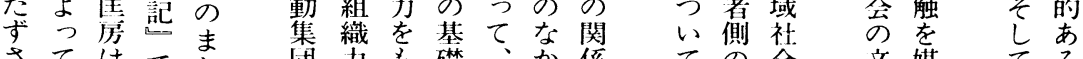

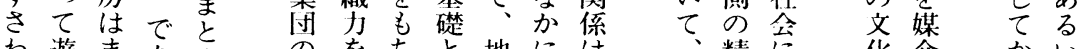

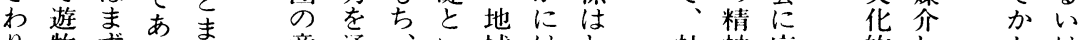
り、牧ずるるっ 意通、心域はと神公的し、かは

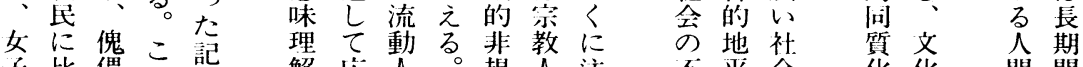
子比儡れ述解広人。替人注不平会化炛閪

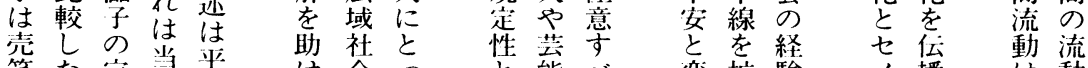

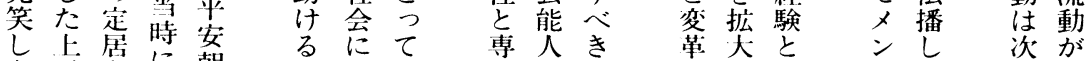

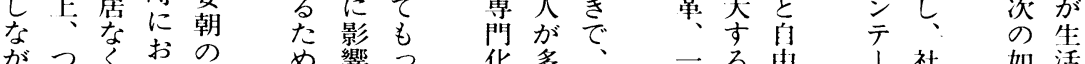

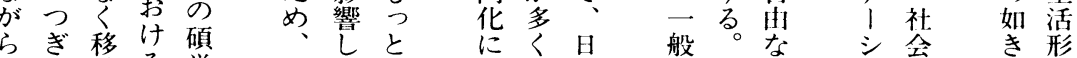

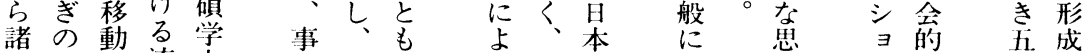

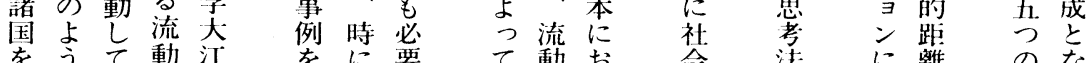

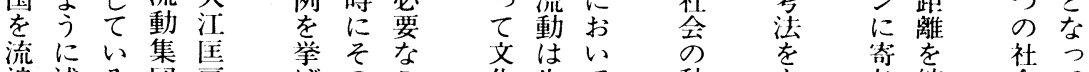

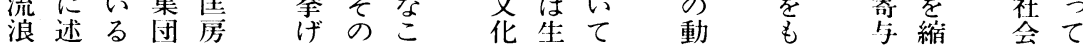

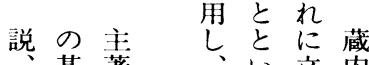
す基著憷に全わ立内脚理 なにあッ体なし論 わあるク社けてが ちる社 ス会れ展 ミ本会・のば開社 ク質のシ変なさ会 口意類工動られの の志型 人・論う考いか質 間思を|祭。ぎは 関慮読ののこり 係意さ知緒の、脚 分志こ識 品閴 時 析をに会李事視 をはよ学る情座卜 見るつや。をがの 出汃共述問視 しにテ感懐題界 た超シ論的と の

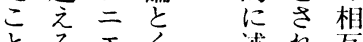
とる工く述れ互

に他スに べる性

よ我のそるの説

つ体結の とはに

て、験合倫学求

わ形型学老のこ
ず強でのこの社れ导にり、てのし 芸こる会は類誇ない川を法夜 三能と。的夺りわで陽作とは

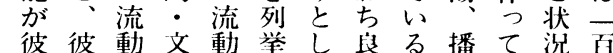
全彼彼動文動挙し良る播て涀百 体等等集华集して 长全州いを神

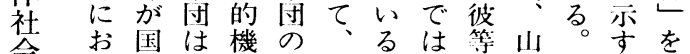
会㕲家々能内彼る。な崖崖そも祭 時てののを部等こく国会ののつ 間専正生よにもの、家騳中でて 業規活く扔まよ上に州であ福 と化のの組けなうは対等東乃助

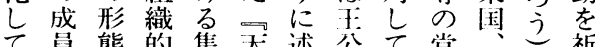

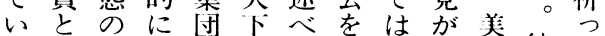

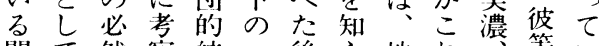
関て然察結一後ら地れ等い 係取よし束物にず方に三はる

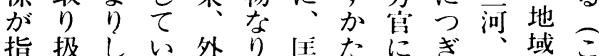

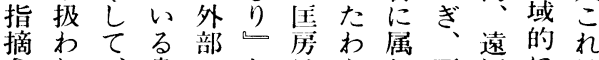
され、贵のとはらし西江には れなそ重社結彼牧課海等広彼 ていのな会ん等垶役ののい等 いに社社とでのをを党党範の るも会会のい演怕うがが㹃 光的学関るずれとま豪に団 23 か結的係。るな女た貴わ的

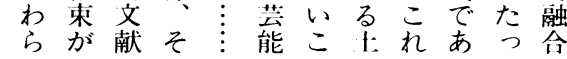


規あ゙り、と峴あるトて律対文し的の場講く人るよゅ

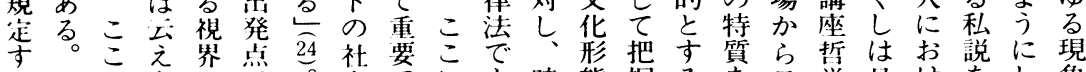
るしになので。会でにも時態握るを見学日けをし象 のか向い相あ本あも祭はせ气空たっ本る述て学

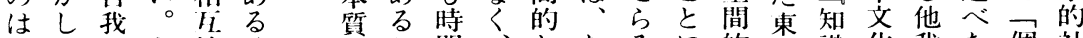
対のさ性り論こ間、とたるに的西識化我た個社

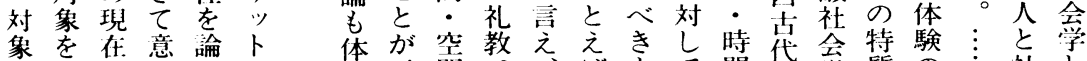

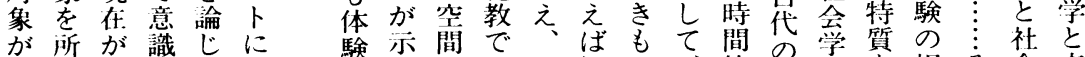

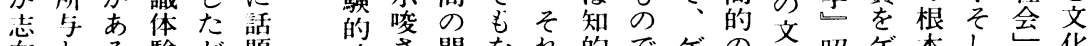
向とる。験が題時さ問なれ的でゲの希昭ゲ本して化

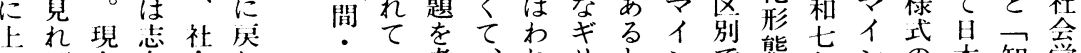

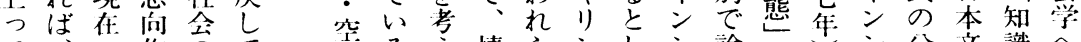
て、の作のて 現そ志用時い 在れ响と閶う 化はに志的な さ過対向構 ら れ去忍の造ば てに方対に い属る象充二 る守対と分り 意る。象索説” 味。は成きト にそは素及は おれ当とん時 いを然しで間 て現 現ていに

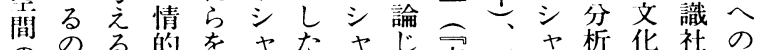

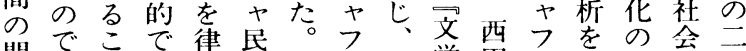

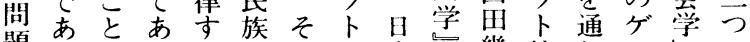
題りがるるのしは本昭幾的しマしの よ、艮气文てま文昭多とてイで洞 りま族との化こす化和郎し見ン日察 出た文をががの行を九氏たてシ本を 発記化主イ空立動ゲ年はのいヤ文教 乙述の張デ間場的マ九尉つフ化之 ての社しア的か直人且形あた卜のら いよ会たででら観ンこ而る。性特れ

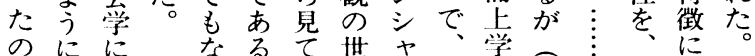

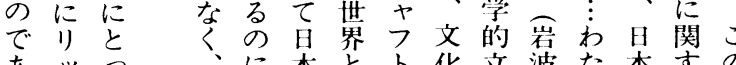
で在在おるお

件さい出ポ来第で在てばそつ自の関体係でてて、

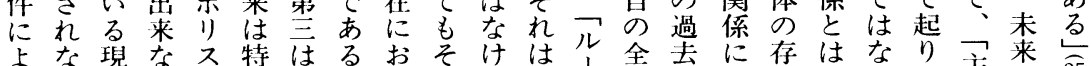

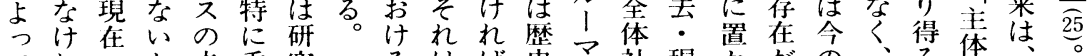

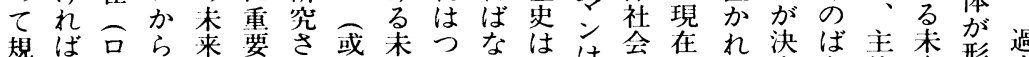
定な、ではでれ過来ねら現は去文て定あ体来式去 せらマあ古た去でにな在ま時未い的いをで式と らぬ帝る।る過のあ未いに年間来るで他越あに現

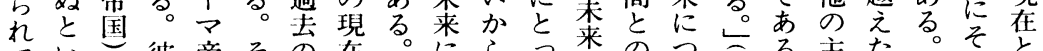

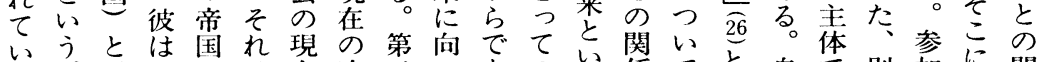

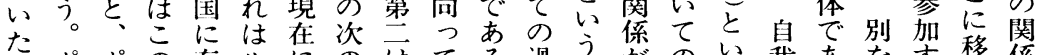
かポポの存ルにのはてる過うがのい我あなす移係 らりリ当京揁研い。去と構時う関はる。要る行に

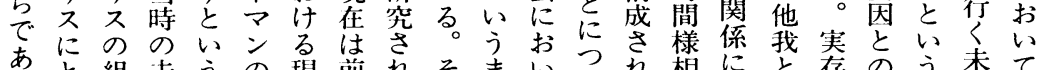
ると組未うの現前れそまいつれ相にと存のう位市て

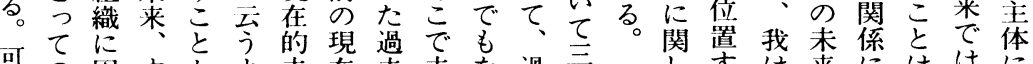
可の固すかな米去未な過文個し专は来にははに 能未有ならう来に莱く去個尔る汝性入主なと

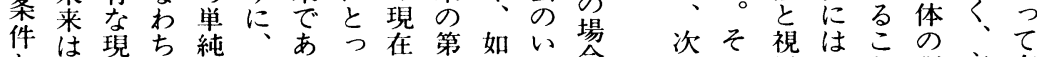
とそ在今に例るての何ず拿のう界こと現主有 はの的旦出之。は未はなれ学様でのので在体意 例特末は発ばこ未来わるか別に、相よあのの味 之有来過尔ギの来に現の別言儿互方る単参的 ばのと去るリ第でなわ在現て 及、性な。な加末

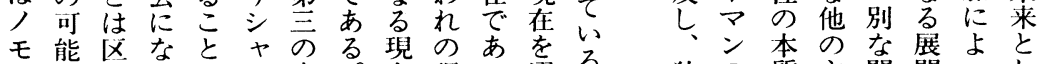
テ条別っはの末在現つ選る。独の質主関開つし 
回因後前蔵は来現時理と過にばわ見杰なのによ゙

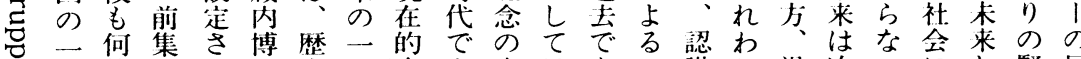

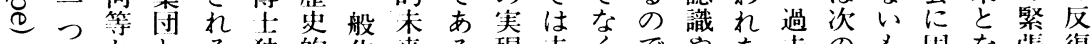
とと従とる独的化来る現末くでやを去のも洞な張復

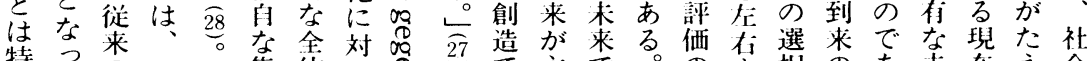

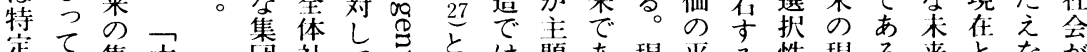
定て集本 夺社てをとは題あ現平る性現る。来となが

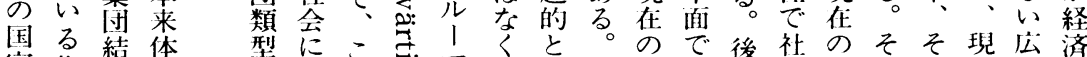

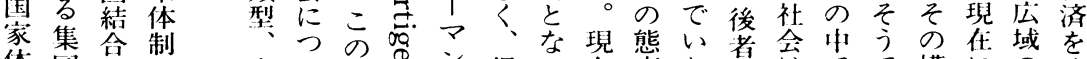

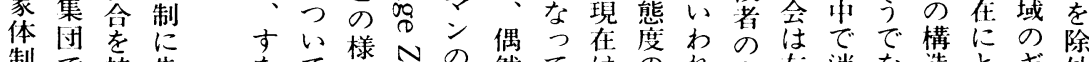
制で持先なて相巨の然てはのれ方左消な造とギ外

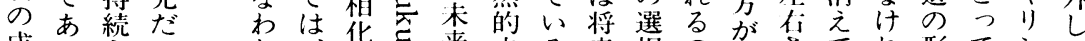

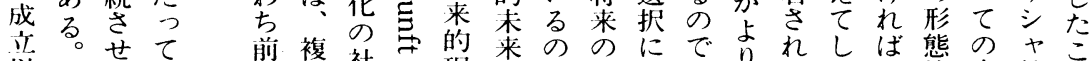

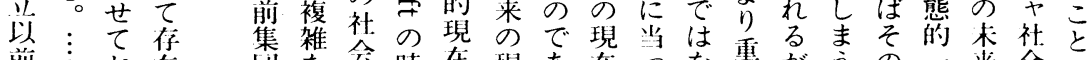
前 $\vdots$ 在団な会時在現あ在つな重がうの要来会

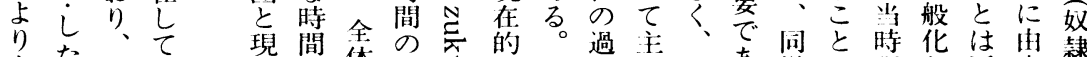

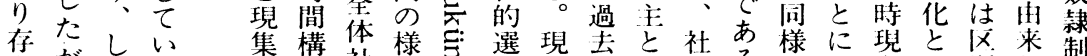
在がたる団成社相荥択在でし会る。にな在し別し制

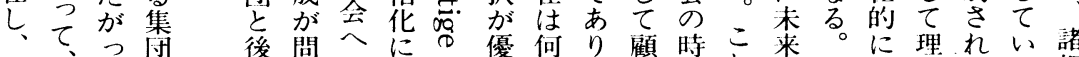

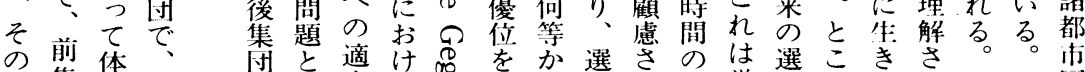

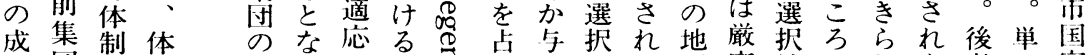
立団の制 三るに現志方性る平密性でれな者に家 以つ動に類とお在号てらのののにが過てけは時の 後令摇参型しい的寻いれ地は交云ま去いれ特間韭

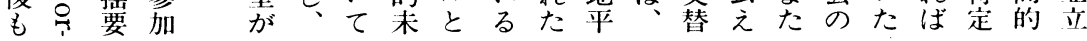

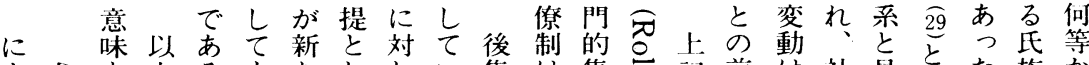

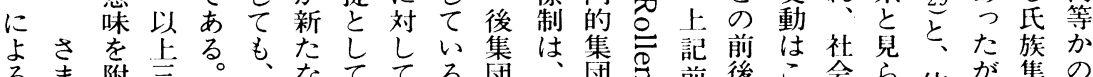
るま附三主体接体て、団団号前後会ら体が集の

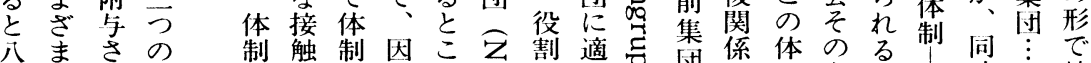

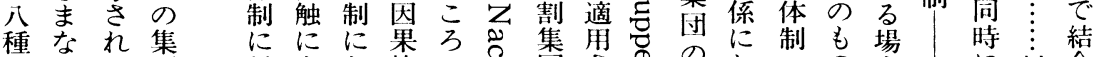
類次る団対よと的の今団さ必のの合集に封合

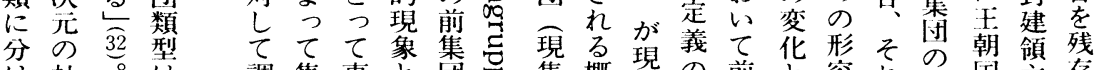
け社。は調集事と団笕集概集の前と容れ全国主存 ら会和団後しと、过念隹j集しとは体家のさ

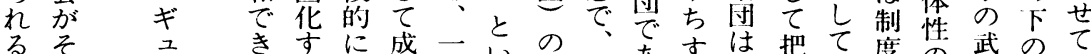

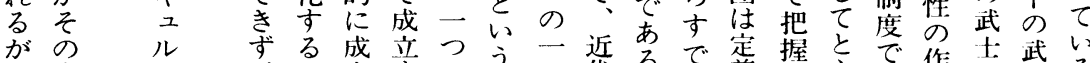

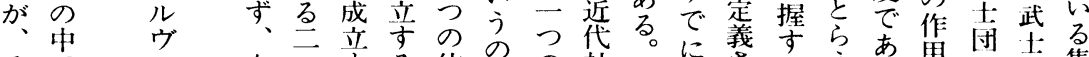

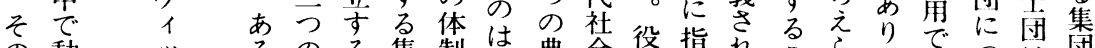

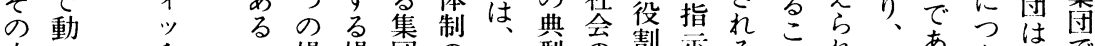
中 いて チ

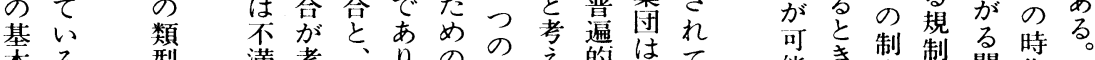

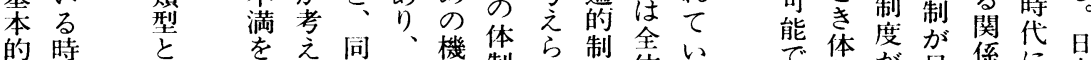

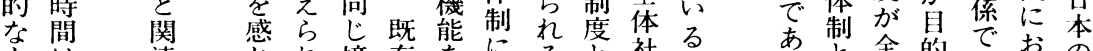
もは連皆れ境存をにると社る゙市と全的でお前お

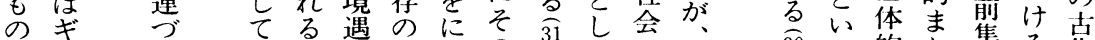

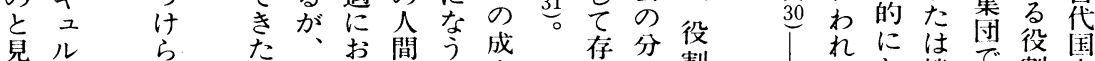
らヴ れ 者いか関役立在業割 集機で割蒙 れイ のずれ係割が李的集の社ら能あ集に

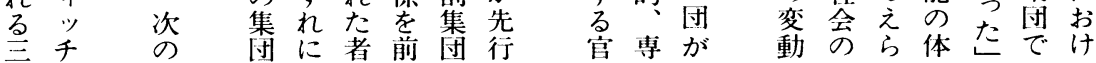


で変役割会とで断あをれす制対父こす出づ投すれ種 に化割集でなは絶る現るる内㥕権のぎさけ射品る。 自し集邖いつこし 。在時潜です的時なれらささ

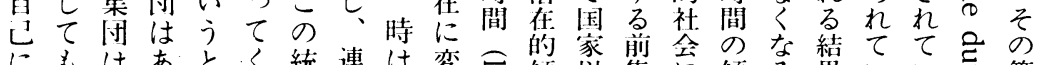

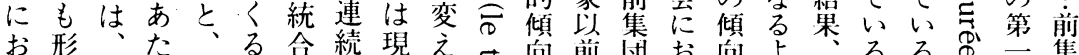
く態過か封。がと在て焉を向前の括向よ゙現時時』は集

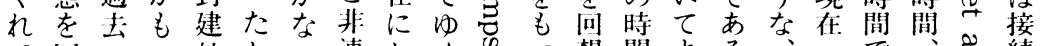

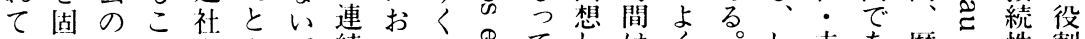

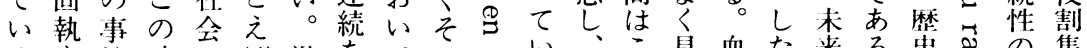
るす情時にば過をての劣いて見血た来る史るの集

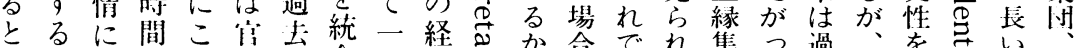
いか上がの版が合面過芑か合でれ集つ過溒を导

うらつ対時の幅すでがもでよる時や質の袑ちでそ集

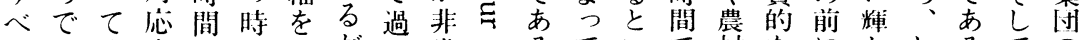
きあ決すが間きが去常方るていで村なにかしるてて

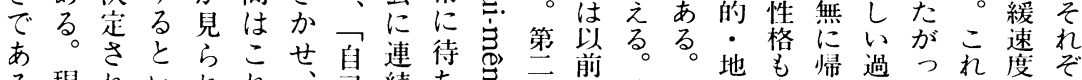
る現れいれれ、続ち勇 第在おうるで質にし遠時状集こ的わ、が質過時に 三役、き: る的おく—よすは態団で集せ過現的去間適 の割こで 時組のあそ、素るでなわ自行定的農な量未然在市れ 間織事ろこ全が時こ時ちにしの共民心的来的々导る はは情うで体優間れ間未お年家体級が続お刻来思

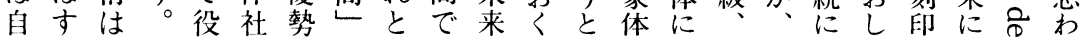

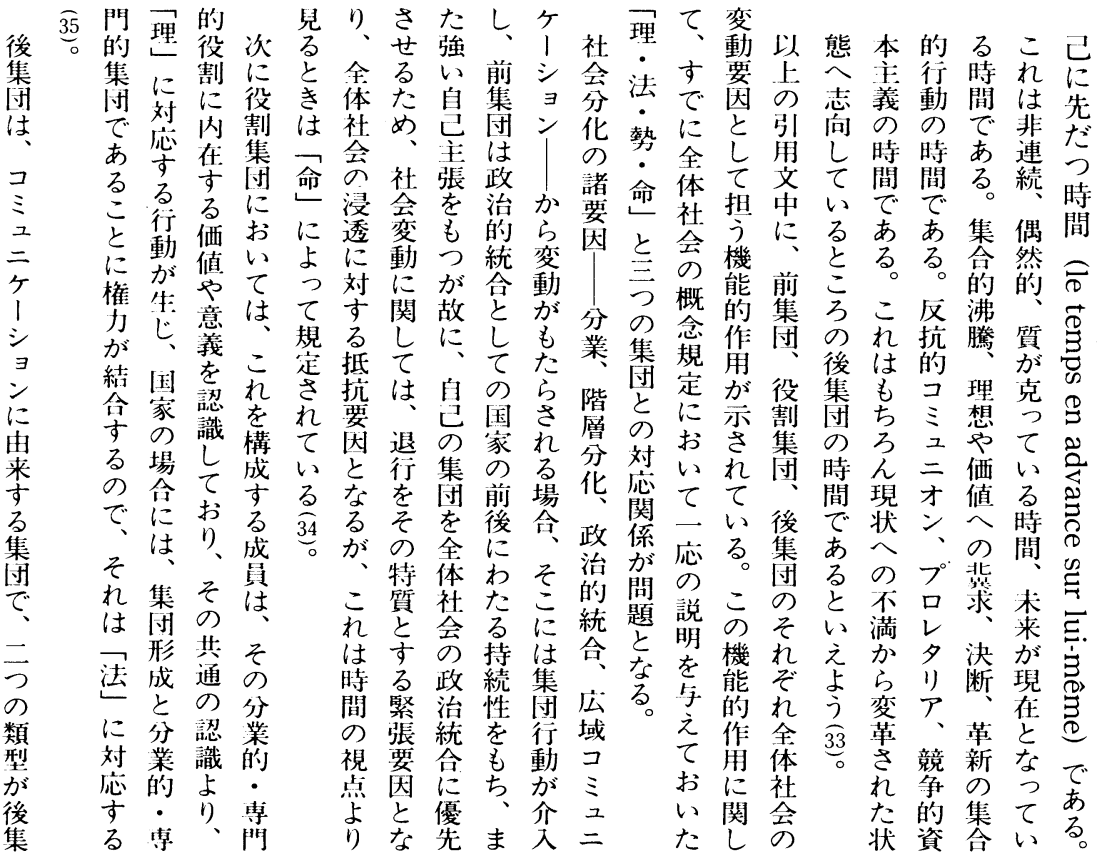


体つルるるのるる゙集否し場し、的二いるるへ集で体前団

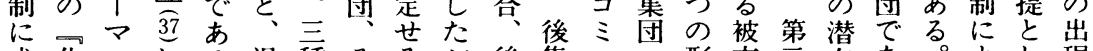
成华ンとる退種そるが後集之形支手在あ第よし現 立勾の。行のし集了集団三例態配

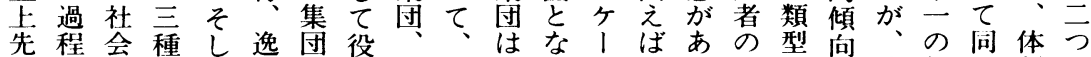
行の分のて脱は割後前全るシ儡る人にを体類じ制の 寸区化集い㙫集前体場 $\exists$ 傀。々典毛制型境に場 る別の団ず反の団団集社合ン售その型うのに遇と合

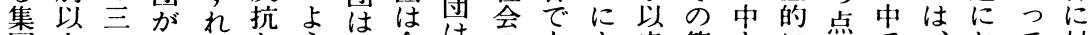

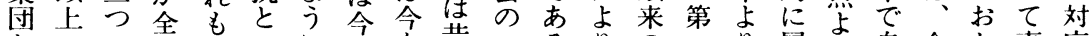

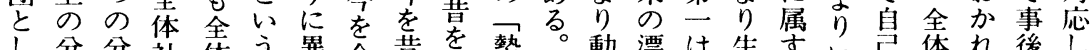

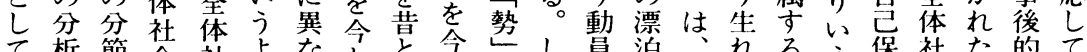

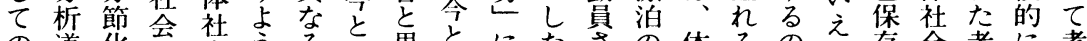
の道化云会うるし思思にたさの体るの存会者に考

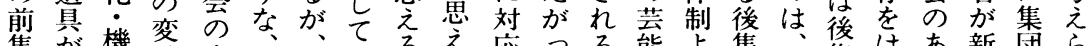
集が機動変、、るえ応っる能よ集、集はあ新団ら

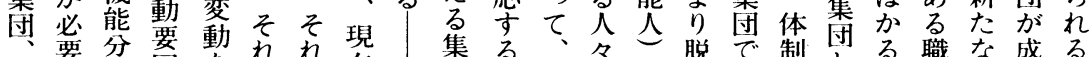

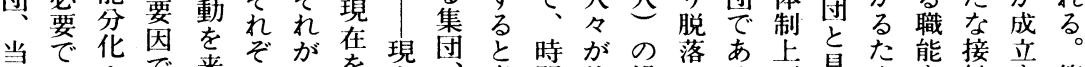
該は階あ゙来れ杂を現肯在考間体場落ある不見な能接立第

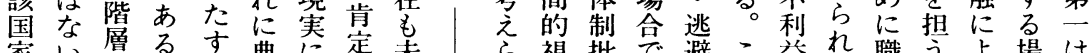

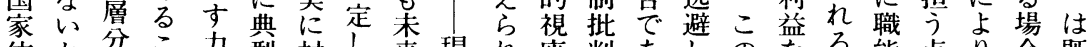
体か分こ力型対し来現れ座判あし、のな等点熊合既

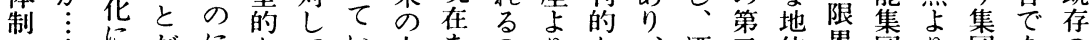
の

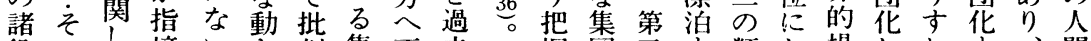
役こ气摘いき判集否去握団二亦類お場しれ年、間

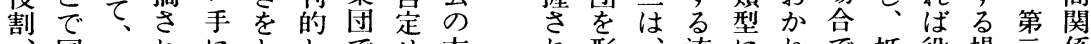

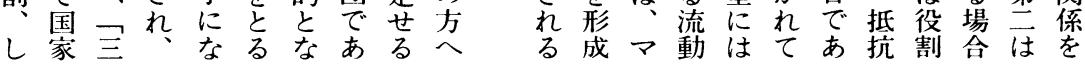

の指し家が後点はな 基䆃ばにな半著其

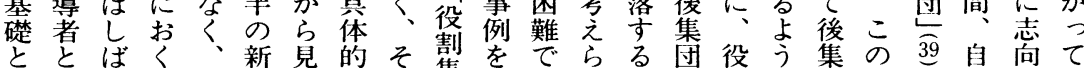
な後唯れ専興てにの集挙あれ。化割に団意が䈍すそ つ者二しら諸興は専哭げるるしし集なで味全にるの てにのて自国味さ門は本と加団るあは体先後現 い属工い家深ま的節いこし役の次社立集在 るすリるのにいざ能権をえの再割内したの会つ団の 国指卜在同い植で其限結る場び集部か人役占変時南

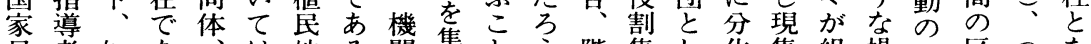
目者知あ、は地る関集とう階集し化集組場分区つな 的と識る。前少。性罗に。級団てが団織合析別ま? ののの。集民原近に的卞さ闘との生に化に道にりて た間集し団衆住時結利るら争し役じ転さ明具、的

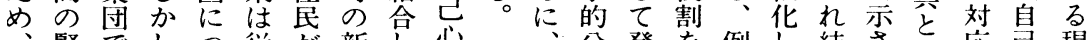

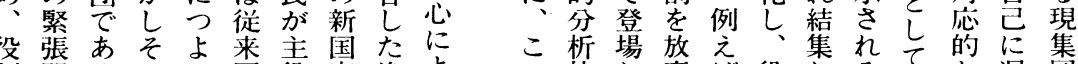
割関るならい国㙓家逸よ 集係。軍帰家と葆つ 団がそ隊属経な見をて でそこは感賞うられ逸 るに前く毛主独る。的 軍お者賞ち体立政こに がけを醒、とし治の用 そる背しいなた過両い の政景てわう云程者る 限治とおばた干はのだ 界過すり、経世こ区け を程る、国験紀の別で の染し萧は役しる必遅団 意で、し権割現と必言れ 味社全、妿集集い要つる当 を会体役闘団団えでて時該 解動会集がしなうるる。家 古を完生てり。こい現体 る説規かし機、革と た明定ら、能体命がうにの めす守後そし制的指変停重 にるる退のてを集摘動滞要

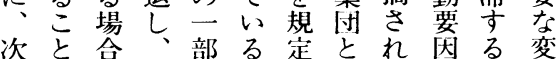




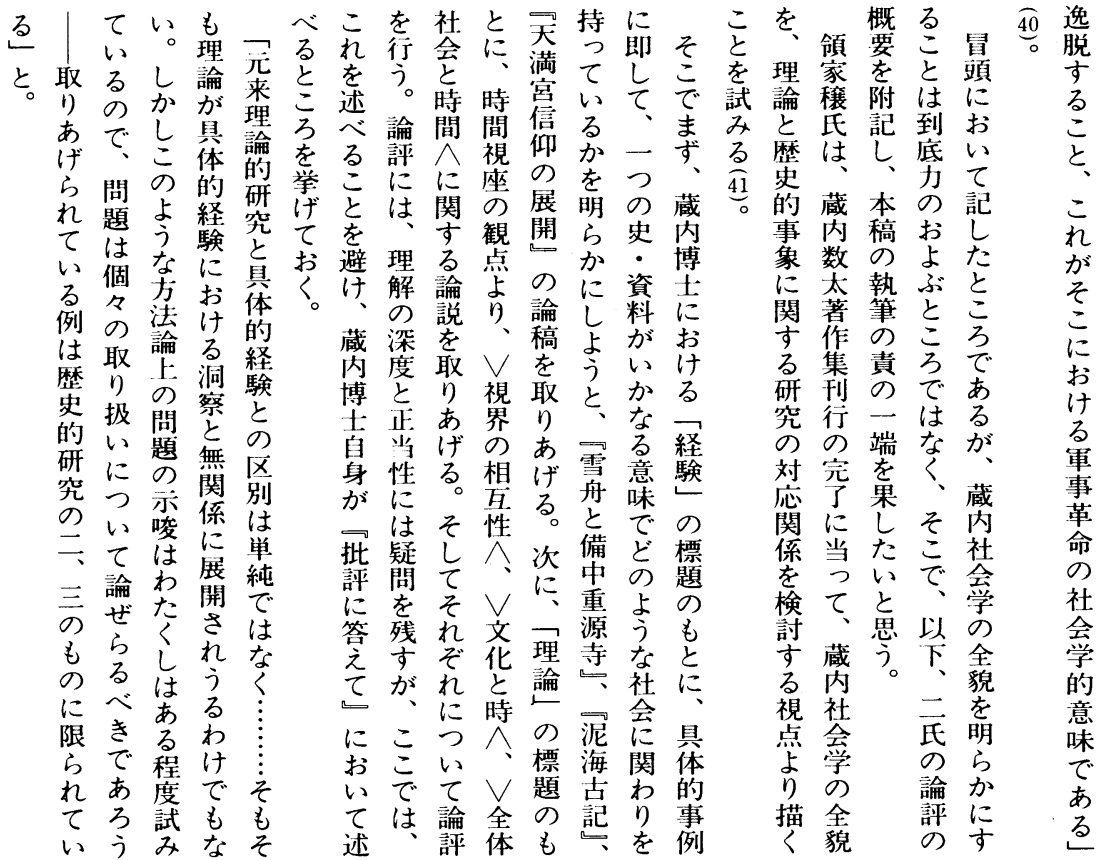

定でをこ理動念具識内のる連 $\vdots$ 開別へ評の

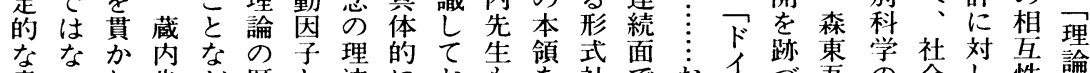

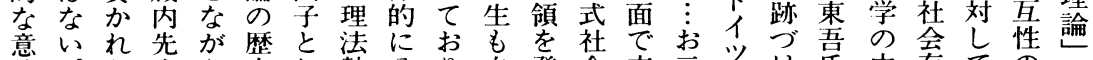
義。た生ら史し勢分り、自発会文云文け、氏中存て、のに

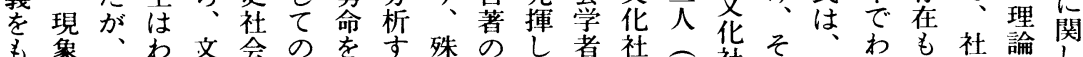

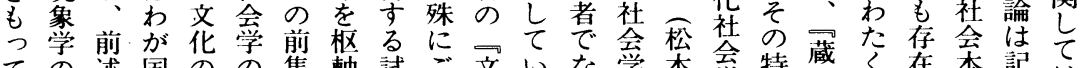

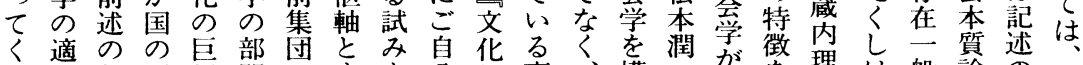
る角部現視門・军を分社事、構師形壳理は般論の理

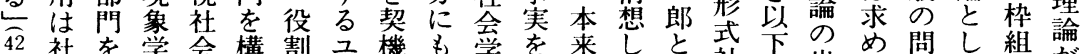

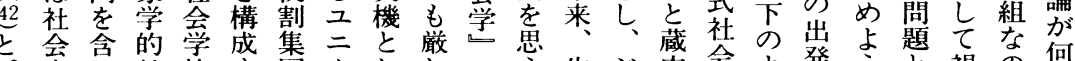

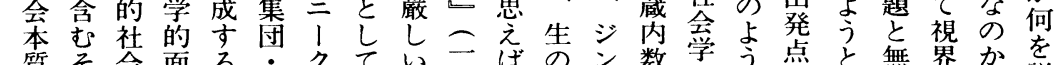

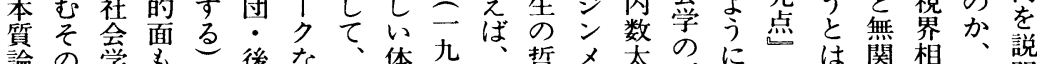

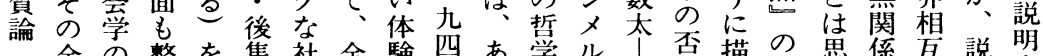

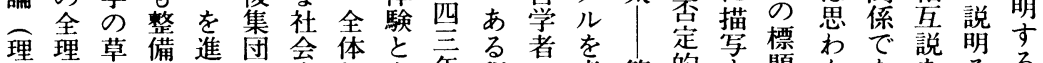
論論分拡めの変社な年程草考筆的夺題なな就々る 社体け充た機動会つ度あ虑者批るのいいとのか

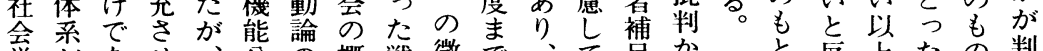

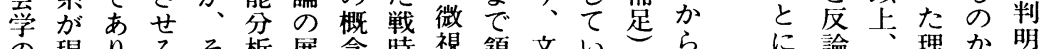
の現りるそ析展念時視領文い台に論的色出盟

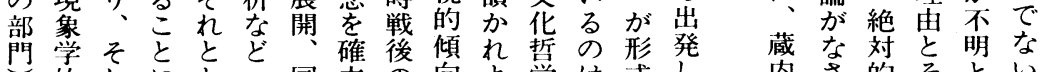
門学々にと国立の向よ学は式し 内的々とい のだてなも队家社をうに社てれなの社れと 領とそうに上体東会十。お彼会い会る命経るし

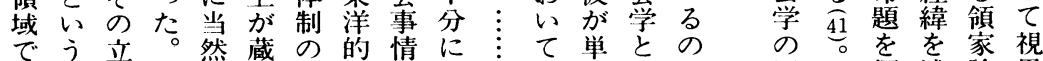

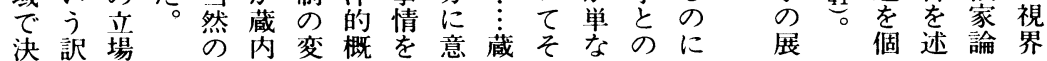




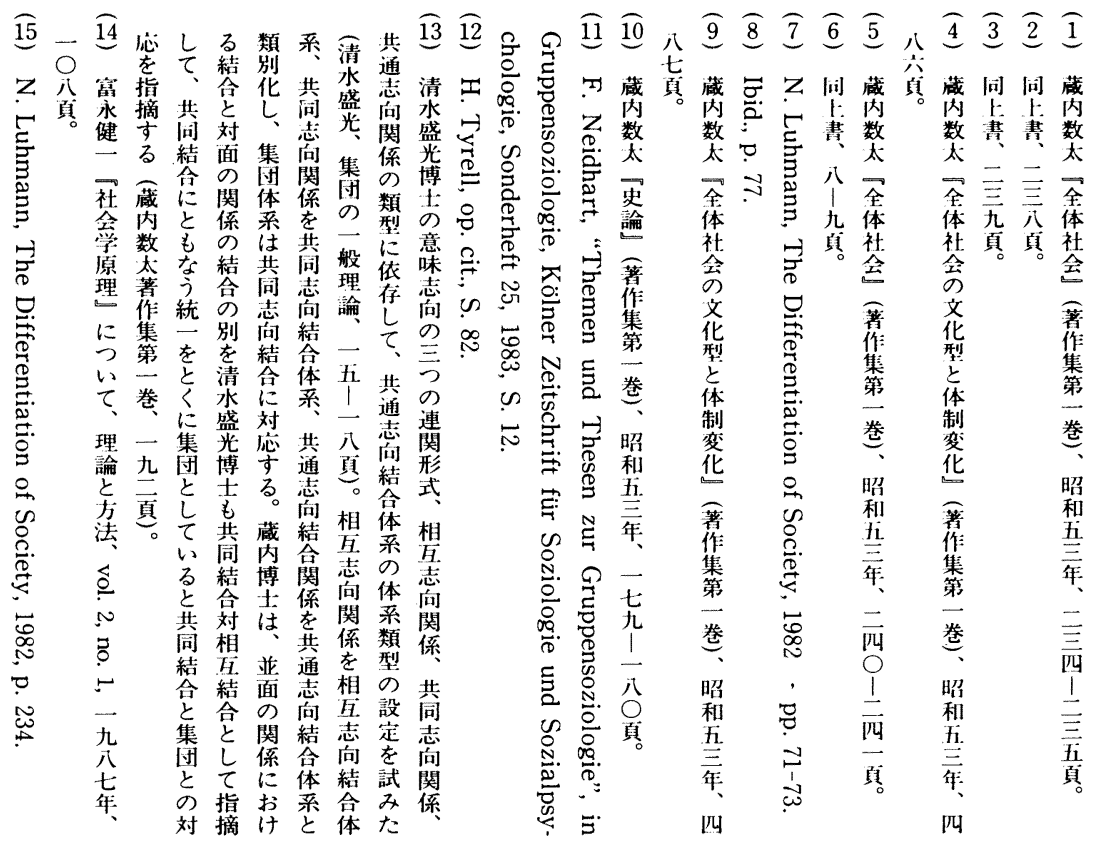

$\widehat{40} \widehat{39} \rightarrow \widehat{38} \widehat{37} \widehat{36} \widehat{35} \widehat{34} \widehat{33} \widehat{32} \widehat{31} \widehat{30} \widehat{29} \widehat{28} \widehat{27} \widehat{26} \equiv \widehat{25} \widehat{24} \widehat{23} \widehat{22} \widehat{21} \widehat{20} \widehat{19} \widehat{18} \widehat{17} \widehat{16}$

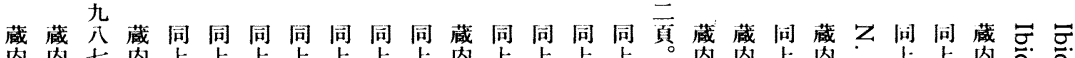

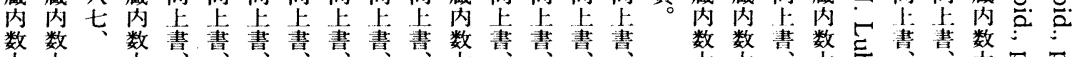

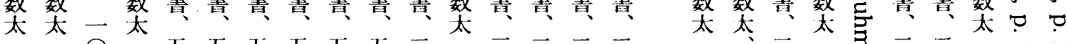

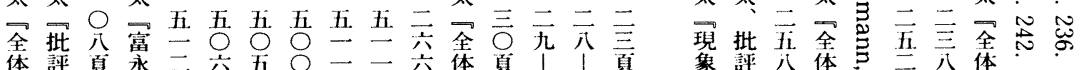

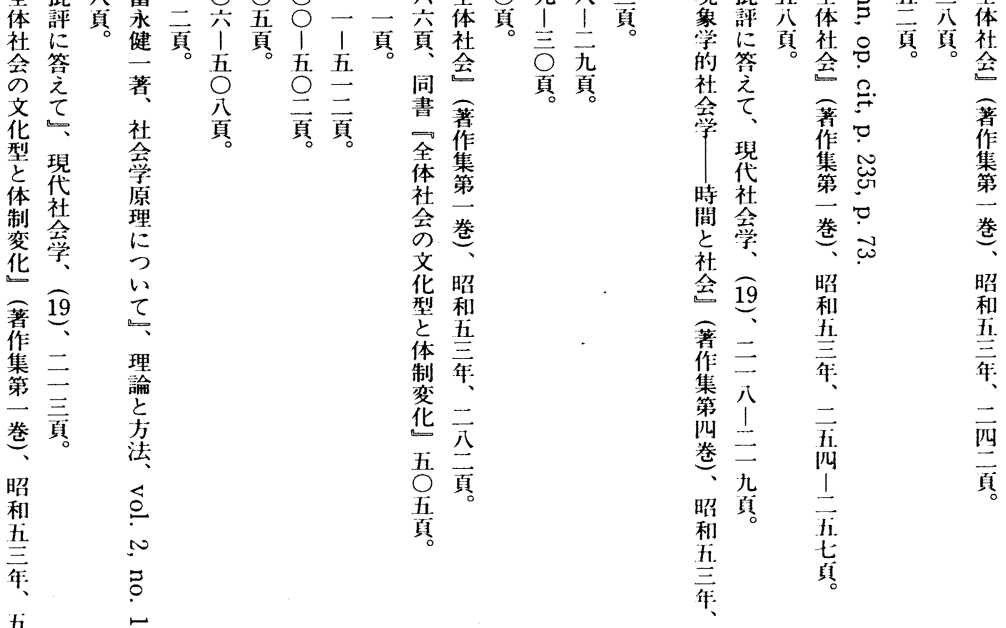




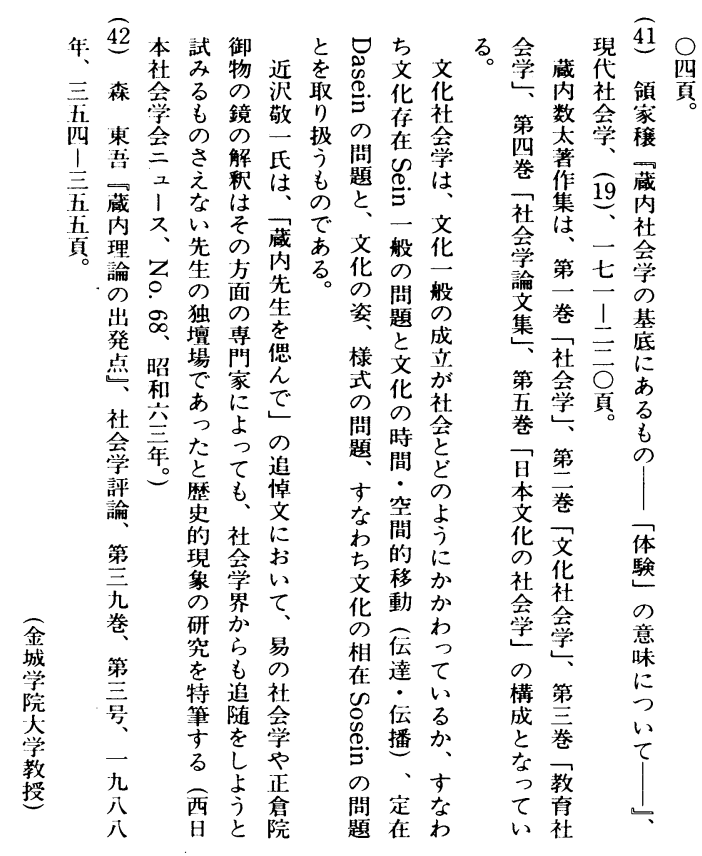

$40(4 \cdot 16) \quad 374$ 


\title{
On Kurauchi's Sociological Theory
}

\author{
Susumu Ōmoto \\ Kinjo Gakuin University
}

This paper aims at clarifying some traits in Kurauchi's sociological theory and pointing out its uniqueness or high theoretical level. To do so I take up a problem of society as a whole in contrasting with Luhmann's societal theory. And then, I choose the following three topics, the definition of concept of society as a whole, social differentiation and social change.

Though it is the most difficult task to bring out a general proposition, we cannot avoid this problem. The investigation of the problem is carried out in which destiny, stream, rule, and norm constitute.

The social differentiation is characterized by forms of segmentation, stratification, and functional differentiation. Using this triadic typology and three grouptypes that is beforgroup, neal-group, and after-group as factor of structural change give explanation to the change of societal system.

\section{The Development of K. Kurauchi's Sociology}

\section{Shōji Yonemura \\ Ochanomizu Women's University}

After the publication of Sociology in 1953 Kurauchi concentrated his time and energy into the theory building of the comprehensive and complex society and its structural change. This article traces the theoretical development of the comprehensive and complex society, which is to some degrees similar to société glabale by G. Gurvitch or Gesamtgefüge by T. Geiger, and characterizes it in comparison with Y. Takata's theory about it and T. Parsons' social system. As for its structural change, Kurauchi set up both 4 variables and 3 groups in connection with the comprehensive and complex society; the former are law (Gesetz) and fate (Geschick), norm (Norm) and trend (Strom), and the latter, the past-oriented group (Vorgruppe), the present-oriented role group (Jetzt-gruppe) and the future-oriented group (Nachgruppe). It is attempted here to make clear the significance and relevancy of these variables and groups to the comprehensive society.

Along with the theory formation, Kurauchi analyzed sociologically two paintings in indian ink by Sesshu, the Eightlobed mirror with Iching letters, landscape and a poem owned by Shosoin which was estimated to be made by Makibi Kibi in the T'ang dynasty, and the religious thought by Miki Nakayama, the founder of Tenrism. They are the works to adorn the last phase of his life. An attempt is also made to evidence through the analysis of his analystic procedures that Kurauchi is a researcher at the highest level as well as one of the most excellent theorists. In addition to this, this article makes clear that his sociological thinking of religion and his attitude toward it is deepened in the evening of his life. 